\title{
The Ghana Library Services
}

\section{Evelyn JA Evans, former Director of Library Services, Ghana Library Board looks back over the foundation of the Ghana Library Services:}

\section{How Ghana Libraries Services began}

Looking back over the steps undertaken before the Ghana Library Services were established, it seems very important that so much preliminary work was embarked on. First a country-wide survey was made, and a detailed plan worked out of the future development, taking into account the educational system, the general standard of literacy and the rate of its increase, the languages in common use, population distribution, the transport and communication systems, the demand - as opposed to the need - for books, the pattern of local authorities and their view on the principles of library provision and - very importantly - who would ultimately be responsible for the financial needs of the library system, the purpose of the library provision and what it hoped to achieve, the resources needed for the Services and draft estimates for the first five years.

Once these estimates and draft plans were in place, legislation was required to enable the appropriate authorities to implement these plans.

The Gold Coast (now Ghana) was fortunate in that the British Council had introduced the idea of libraries into the country and had set up a Library Advisory Committee, initially to advise its own librarians as to their role in the then four British West African countries (Gold Coast, Nigeria, Sierra Leone and Cameroon). This Library Advisory Committee then divided and a Library Advisory Committee to the Gold Coast Government was set up. Its role was to put forward suggestions for library development and, with the aid of the Law Department which drafted the relevant bill, a Library Board was established. The Gold Coast Library Board Ordinance, 1950, was the first law enacted for the establishment of public libraries in the whole of West Africa. This then became the model for the establishment of public libraries in many other countries. Section 6 of the act reads: 'It shall be the duty of the Board to establish, equip, manage, and maintain libraries in the Gold Coast, and to take all such steps as may be necessary to carry out such duty'. The simplicity of this section gave full authority to the Board to get on with the job of library provision, without tying it down to specific procedures.

The British Council librarian became the first Director of Library Services and Secretary to the Gold Coast Library Board, one of three expatriate staff appointed to initiate libraries, the remaining two being her Deputy and a Cataloguer. The Board then concentrated on two matters: the provision of books and the training of local staff. All three expatriates were involved in in-service training of local personnel. To begin with the local staff sat for the British Library Association examination, the first examinations being taken locally. Then staff were sent on to British Library Schools to complete their Associateship and Fellowship. Later Ghana founded its own School of Librarianship.

Having made an initial survey, the Library Board took decisions about the establishment of libraries. Premises were available in Accra and a Central Library Headquarters was established there. Elsewhere temporary premises were used as the Board wisely decided that the need for books was urgent and readers should have priority over new buildings. A decision was also taken that no permanent library buildings would be opened until qualified staff were available to run them. Meantime books were sent to individuals by post and a book box service was started to provide books for schools, colleges, community and social centres, mines, hospitals, etc. -50 books to a box. Readers were asked to respond in terms 
of the books they would like, the subjects in which they were interested and these answers were recorded so that mobile libraries which visited all the centres four times a year, carrying books for exchange, could include any special requests.

As the book stock increased and qualified staff became available, the question of library buildings was reconsidered. Ghana has an area of 92,000 square miles, divided into administrative regions. It was decided that the first new building should be a Regional Library for the Ashanti Region and further regional libraries would be built before a major new library headquarters would be built in Accra. The Board was anxious for it to be understood that it intended to run a nationwide service and not just an Accra service. The final goal would include headquarters in Accra, regional libraries in all of the regions, fulltime branch libraries, evening centres and mobile library services within each region and the development of these would be the responsibility of the regional librarian. There would be some centralisation so as to avoid unnecessary duplication of work and to make the most of the qualified staff becoming available. Book-buying cataloguing would be centralised for the whole country and books, when ready for circulation, would be sent in bulk to the Regional Libraries.

A major problem facing library staff was the lack of bookshops in Ghana and thus the impossibility of seeing books before ordering. For current publications, the British National Bibliography was received by airmail, marked up, and orders placed within a matter of days, but there was the inevitable delay of books having to be sent 4,000 miles. Lists were compiled from various bibliographies for the major bookstock and publishers were cooperative, sending proof copies of books, detailed catalogues, book jackets, etc. Once a year publishers' representatives would visit the country.

At the end of the first five years, the Library Board could look back on a period of quiet achievement. Fulltime libraries had been opened in seven towns, three children's libraries had been built in Accra (with a grant from a local trust), one Regional Library had been built and a second was under construction, and the first plans had been approved for a Central Library Headquarters. Postal services and book box services had been provided for readers outside the areas covered by fulltime libraries, and three mobile libraries were on the road to supplement these services. A special service for teachers had been organised, a new profession had been introduced into the country and in-service training was well in hand. Scholarships had been awarded for staff to attend British Library Schools and the Board's plans had been accepted by Government as part of the country's first five-year development plan, an important point as the major part of the Board's income came from Government.

Ghana has been fortunate in that both the colonial government and later the Ghana Government were interested in and supportive of library development, the Central Government grant being supplemented by grants-in-aid from towns where the Regional Libraries were established.

The Ghana Library Service has been, and continues to be, a great success. It is a service financed almost entirely from local funds and, as the first President of Ghana stated 'The provision of library facilities for everybody throughout the length and breadth of the country, was recognised as an essential element in the national scheme of educational advancement'. Its importance was acknowledged by Government from the beginning, and the necessary funds were supplied. 